\title{
Political Connections and Tax Avoidance in Indonesia
}

\author{
Bambang Ahmad Indarto and Wahyu Widarjo
}

\section{ABSTRACT}

This study aims to provide empirical evidence on the effect of political connections on tax avoidance practices, as well as the effect of electoral year moderation on the effect of political connections on tax avoidance practices of companies listed on the Indonesia Stock Exchange between 2013 and 2019. The results of the analysis of $\mathbf{1 0 8}$ samples show that the political connections of the board of commissioners have a negative insignificant effect on tax avoidance. The electoral year cannot moderate, strengthen, or weaken the influence of the board of commissioners' political ties to tax avoidance. Furthermore, this study also discovers a significant negative effect of the board of commissioners' political connections on tax avoidance in companies with a high level of leverage.

Keywords: Electoral Year, Political Connection, Tax Avoidance.
Submitted : October 10, 2021

Published : October 31, 2021

ISSN: $2507-1076$

DOI: $10.24018 /$ ejbmr.2021.6.5.1136

\section{Bambang Ahmad Indarto}

Faculty of Economics and Business, Universitas Sebelas Maret, Surakarta, Central Java, Indonesia.

(e-mail:

bambangahmadindarto@gmail.com)

Wahyu Widarjo*

Faculty of Economics and Business, Universitas Sebelas Maret, Surakarta, Central Java, Indonesia.

(e-mail: widarjo@staff.uns.ac.id)

*Corresponding Author

\section{INTRODUCTION}

Almost all countries in the world, including Indonesia, rely on state income from the tax sector. The Posture of the State Revenue and Expenditure Budget (APBN) in 2019 released by the Directorate General of Taxes noted that $82.5 \%$ of state income came from the tax sector [1]. Corporate income tax is a major concern for both businesses and governments. The company tries to manage tax obligations efficiently to reduce corporate tax costs, but the government also has a responsibility to maximize state revenues from the tax sector. The amount of tax liability arising from taxpayers' business encourages many tax avoidance practices. Recent research on tax highlights that aggressive tax avoidance is risky [2] and [3]. Overly aggressive tax planning can be associated with the risk of falling stock prices [4]. As a result, for a sample of international firms, political connections are positively related to corporate risk-taking [5], because political connections serve as an insurance mechanism against extreme events [6]. In other words, connected firms may engage more in tax planning because of the higher risk-taking tendencies caused by political connections.

Several researchers have previously investigated the relationship between political connections and tax avoidance. According to research [7], the entrenchment effect of controlling shareholders has a negative effect on tax avoidance. The role of external audit quality and commissioners has not been shown to weaken the relationship between controlling shareholders' entrenchment and tax avoidance [8]. Political connections have a negative effect on tax avoidance [9]. The Panama Papers and Paradise Papers data demonstrate the extent of the potential for tax avoidance [10]. This is supported by the finding of the Indonesian Forum for Budget Transparency (FITRA), which claims that tax avoidance in Indonesia totals Rp. 110 trillion per year [11]. These findings are consistent with previous research [8], [12], and [13] which concluded that political connections have a significant effect on tax avoidance. According to the findings of a study conducted on companies listed on the Indonesia Stock Exchange between 2007 and 2013, politically connected companies pay lower corporate income taxes than non-politically connected companies [14]. The legislative structure in Indonesia, many of whom are businessmen as members of the House of Representatives (DPR), is indicated to have affiliations with as many as 1,016 limited liability companies in various sectors, with a dominance of $45.5 \%$ or 262 people from 575 members of the DPR for the 2019-2024 term of office [15]. Political connections in the executive and legislative branches do not violate the rules legally, but it is difficult to separate personal or group interests from state interests ethically.

This study differs from previous research in several ways. First, this study examines not only the effect of political connections on tax avoidance but also the effect of the electoral year on tax avoidance practices. The electoral year determines the direction of political power to gain access to benefits from the government's strategic policies so that politically affiliated companies are more likely to provide a stage for these politicians to gain more votes when the general election is held. Second, most previous studies focused on 
determining tax aggressiveness using the Effective Tax Rate (ETR), GAAP ETR, and Cash ETR. In this study, tax aggressiveness was measured using Abnormal Book-Tax Differences (ABTD), which were calculated from the residual value of the regression estimation model of Book-Tax Differences [16]. ABTD is considered to be more accurate in measuring tax aggressiveness because it contains information that can reveal the difference in book value between accounting profit and fiscal profit managed by company management.

Third, in determining the object of research, this study has a more specific focus. The researchers focus on companies that have characteristics and indications of political affiliation, which can be seen through the company name, management structure, and the appointment of political party elites to fill certain positions in the government. The composition of the board in this study focuses on the board of commissioners since this position holds a very strategic place in the company and has the authority to oversee the company.

The following section of this article will explain the theoretical foundation and hypothesis development, as well as the methodology and research findings. The conclusion, limitations, and recommendations for future research are presented in the final section of this article.

\section{THEORETICAL BASIS AND HyPOTHESIS DEVELOPMENT}

\section{A. Political Connection and Tax Avoidance}

Political connections are the company's strategy for establishing and maintaining positive relationships with politicians through lobbying, political donations, campaign contributions, or the appointment of politicians or bureaucrats to boards of directors. In other words, fostering political connections is an important strategy for businesses seeking to influence the government in designing favorable policies. Companies with political connections will have easier access to capital loans, government protection, and low tax audit risk, causing companies to be more aggressive in tax planning, which impacts the opacity of financial transparency [8] and [12]. With political connections, the company can obtain a variety of benefits. Even if a financial crisis occurs, the company will easily obtain government bailout funds [17].

Agency theory describes the existence of information asymmetry between owners and company management. The assumption underlying agency theory is that there are two distinct interests between owners and management, with each party attempting to achieve the desired results. In less-thanideal conditions or when there is information asymmetry between management and company owners, it can provide opportunities for management to engage in opportunistic earnings management [18]. Agency theory is widely used to observe and explain the relationship between the principal and the agent, as well as how to minimize the cost of conflict of interest [19]. Political connections can be thought of as an implicit contract between a company and politicians or bureaucrats, with the company serving as the principal and politicians or bureaucrats acting as agents [20]. Companies seek to gain favorable policies and preferential access to government resources by utilizing politicians or bureaucrats [21].
This argument is consistent with the Resource Dependence Theory, which holds that political connections enable firms to reduce the uncertainty associated with unfavorable regulation [22]. Politically connected companies do not want to pursue a tax avoidance strategy because the company's ties to the government have increased public scrutiny, and such tax avoidance will damage the reputation of the company as well as politicians affiliated with the company [23]. Tax avoidance can be a risky activity if it leads to social sanctions such as a consumer boycott. Based on this, we propose the following hypothesist:

$\mathrm{H}_{1}$ : Political connections affects negatively toward tax avoidance

\section{B. Pollitical Connection, Electoral Year, and Tax Avoidance}

A relational political connection (RPC) is developed through trust and goodwill. Companies maintain long-term relational connections over time, even across regimes, due to shared political ideologies. Ideology is regarded as the most important factor in establishing political connections, so politicians tend to be opportunistic [19]. When the political regime changes, it also necessitates good adaptation to maintain connections, even if this weakens the connection when the ruling regime does not share the same ideology due to the reduced closeness. Politicians will fight to win political contestation through general elections by enacting the ideology that they deem appropriate.

The incumbent politician strives to maintain his reputation and increase his popularity as a tax-abiding citizen who has contributed to the country. For the sake of their reputation, the researchers suspect that politicians will use available resources to increase voter turnout during the general election by putting pressure on businesses to pay higher taxes. Increased tax payments will give politicians the impression that they have made significant contributions to the country. Therefore we formulate the second hypothesis as follows:

$\mathrm{H}_{2}$ : The electoral year strengthens the negatively affects of political connections on tax avoidance.

\section{RESEARCH METHODOLOGY}

\section{A. Population and Sample}

The object of this study was the companies listed on the Indonesia Stock Exchange in the period from 2013 to 2019. The sampling technique used was purposive sampling. The inclusive criteria are as follows: 1) companies affiliated with political figures; 2) use of the rupiah currency; and 3) no outliers based on skewness and kurtosis analysis. Based on these criteria, 108 samples of observations were obtained which were then analyzed in this study.

\section{B. B. Operational Definition and Variable Measurement}

Tax avoidance was measured using Abnormal Book Tax Differences (ABTD), which were calculated from the estimated residuals of the Book Tax Differences (BTD) regression model [24]. ABTD is considered to be more accurate in measuring tax avoidance because it contains information that can reveal the difference in book value 
between accounting profit and fiscal profit managed by company management. The greater the difference between accounting profit and fiscal profit as a result of the company's bookkeeping, the greater the ABTD value. This value denotes that the company is more aggressive in its tax avoidance efforts. Operational definitions and measurement of variables used in this study are presented in Table I.

TABLE I: OPERATIONAL DEFINITION AND VARIABLE MEASUREMENT

\begin{tabular}{|c|c|c|c|c|c|}
\hline NO & Research Variable & Indicator & Measurement & Scale & Source \\
\hline \multirow[b]{3}{*}{1} & \multicolumn{5}{|c|}{ Dependent Variable } \\
\hline & Tax Avoidance & & & & \\
\hline & $\begin{array}{l}\text { Measured using Abnormal } \\
\text { Book Tax Differences (ABTD) } \\
\text { obtained from the estimated } \\
\text { residuals of the Book Tax } \\
\text { Differences (BTD) regression } \\
\text { model } \\
\text { Independent Variable }\end{array}$ & ABTD & $\begin{aligned} B T D_{i t}=\beta_{0}+\beta_{1} \Delta I N V_{i t}+\beta_{2} \Delta R E V_{i t}+\beta_{3} N O L_{i t} \\
+\beta_{4} T L U_{i t}+\beta_{5} B T D_{i t_{-1}}+\varepsilon_{i t}\end{aligned}$ & Ratio & [24] \\
\hline & $\begin{array}{l}\text { Commissioner Political } \\
\text { Connections }\end{array}$ & & & & \\
\hline 2 & $\begin{array}{l}\text { Measured from the ratio } \\
\text { between proportion of political }\end{array}$ & PC_COM & $\begin{array}{l}P C_{C O M} \\
\quad \text { Members of the politically connected commissioner }\end{array}$ & Ratio & {$[24]$} \\
\hline & $\begin{array}{l}\text { connection of members of the } \\
\text { board of commissioners and } \\
\text { the total number of members of } \\
\text { the board of commissioners } \\
\text { Moderating Variables }\end{array}$ & & $=-$ members of the board of commissioners & & \\
\hline & Electoral Years & & Dummy $1($ one $)=$ financial statements were published during & & \\
\hline 3 & $\begin{array}{l}\text { Measured by dummy variables } \\
\text { for the years of publication of } \\
\text { financial statements, whether } \\
\text { during the electoral year or not } \\
\text { Control Variable }\end{array}$ & EY & $\begin{array}{l}\text { the electoral year } \\
\text { Dummy } 0 \text { (zero) financial statements were not published during } \\
\text { the electoral year }\end{array}$ & Dummy & {$[25]$} \\
\hline 4 & $\begin{array}{l}\text { Profitability } \\
\text { Measured from the ratio } \\
\text { between earning profit and } \\
\text { total assets }\end{array}$ & ROA & $R O A=\frac{E A T}{\text { Total Assets }}$ & Ratio & [8] \\
\hline 5 & $\begin{array}{l}\text { Leverage } \\
\text { Measured from the proportion } \\
\text { of debt and total assets }\end{array}$ & LEV & $L E V=\frac{\text { Total of Debt }}{\text { Total Assets }}$ & Ratio & [8] \\
\hline 6 & $\begin{array}{l}\text { Firm Size } \\
\text { Calculated using natural } \\
\text { logarithm from the total assets } \\
\text { of the company }\end{array}$ & SIZE & $S I Z E=L n($ Total Assets $)$ & Ratio & [26] \\
\hline 7 & $\begin{array}{l}\text { Firm Age } \\
\text { Measured by calculating the } \\
\text { company's age from its first } \\
\text { IPO to the year the study was } \\
\text { conducted and then } \\
\text { transformed it to the natural } \\
\text { logarithm }\end{array}$ & AGE & $A G E=\operatorname{Ln}($ Firm Age $)$ & Ratio & [27] \\
\hline
\end{tabular}

\section{Data Analysis and Hypothesis Testing}

This study used panel data regression analysis techniques to test the hypothesis. A model specification test was performed prior to regression analysis to select the best regression model. The model specification tests used were the Chow test, Hausman test, and the Lagrange Multiplier test. Furthermore, the classical assumption test was carried out to ensure that the regression model was free from the classical assumption problem. The following is the regression equation used in this study:

$$
\begin{aligned}
A B T D_{i t}=\alpha_{0}+ & \alpha_{1} P C_{\text {COM }_{i t}}+\alpha_{2} E Y_{i t}+\alpha_{3} R O A_{i t} \\
& +\alpha_{4} S I Z E_{i t}+\alpha_{5} L E V_{i t}+\alpha_{6} A G E_{i t}+\varepsilon_{i t}
\end{aligned}
$$

where

ABTD : Abnormal Book Tax Differences;

PC_COM : Political Connection of Board of Commissioners;
EY : Electoral Yea;r

ROA : Return On Asset;

SIZE : Natural Logarithm of Firm Size;

LEV : Leverage of the Company;

AGE : Natural Logarithm of Company's Age; $\varepsilon_{i t}:$ Error Term.

\section{RESULTS AND DISCUSSION}

\section{A. Descriptive Statistics}

Based on Table II ABTD has mean value -0.029, highest score 0.206 , lowest score -0.216 . PC_COM has mean value 0.125 , mode 0 that appears 75 times. Highest score 0.800 and lowest score 0.000 . EY has mode value most often appears is 0 (zero) as much as 78 times and value 1 (one) as much as 30 times. Control variables in the study include ROA, SIZE, Leverage and AGE. ROA has mean value of 0.003 , highest score 0.608 and lowest score -0.595. SIZE has mean value Rp 6.49 trillion 
with a highest score of Rp 19.52 trillion and a lowest score Rp 776.2 billion. Laverage has mean value 0.517 with highest score 0.869 and lowest score 0.121. AGE has mean value 14.06 years, highest with 21 years old and lowest with 9 years old.

\section{B. Regression Analysis}

According to Chow test, Hausman test, and Lagrange Multiplier test, it was decided that the most suitable model was the fixed effect. The test was continued with normality test, heteroscedasticity test, multicollinearity test, and autocorrelation test and the test model showed that the regression model was free from the classical assumption problem. The results of the panel regression analysis are presented in Table III below.

The regression test results indicate that the $\mathrm{PC} \_\mathrm{COM}$ variable has no significant effect on ABTD, with a coefficient level of -0.017275 and a p-value of 0.6157 . The first hypothesis, which states that political connections have a negative effect on tax avoidance, is rejected by the test results. This can be interpreted as the board of commissioners taking care of the risks that may arise if they use political connections to avoid paying taxes. Aggressive tax avoidance is risky [2] and [3]. Aggressive tax planning is associated with the risk of falling stock prices [4]. The results of this test are consistent with previous research [24]. The EY variable does not have a significant effect on the ABTD of 0.7765 . ROA has no significant effect on ABTD with a value of 0.3892 . Leverage has a significant effect on the ABTD variable with a value of 0.0028 . Size has a significant effect on ABTD with a value of 0.0000 . Company age or AGE has no significant effect with a value of 0.1626 .

TABLE II: DESCRIPTIVE STATISTICS

\begin{tabular}{|c|c|c|c|c|c|c|c|}
\hline & ABTD & PC_COM & EY & ROA & SIZE & LEVERAGE & AGE \\
\hline Mean & -0.0294330 & 0.12536000 & 0.27777800 & 0.0033950 & 6.492360 & 0.517480 & 14.0648100 \\
\hline Modus & \#N/A & 0 & 0 & \#N/A & \#N/A & \#N/A & 18 \\
\hline Maximum & 0.20637690 & 0.80000000 & 1.00000000 & 0.60887800 & 19.5254100 & 0.86967800 & 21.0000000 \\
\hline Minimum & -0.21631430 & 0.00000000 & 0.00000000 & -0.59593900 & 0.77625800 & 0.12109400 & 9.00000000 \\
\hline Std. Deviation & 0.08653270 & 0.21750500 & 0.44999100 & 0.12710800 & 0.40724900 & 0.19331300 & 0.12481000 \\
\hline Observation & 108 & 108 & 108 & 108 & 108 & 108 & 108 \\
\hline
\end{tabular}

Source: Data processing results.

TABLE III: REGRESSION ANALYSIS

\begin{tabular}{cccc}
\hline \hline Variabel & Coeff. & t-statistic & p-value \\
\hline$C$ & 0.063537 & 0.850942 & 0.3968 \\
$P C \_C O M$ & -0.017275 & -0.503464 & 0.6157 \\
$E Y$ & 0.004524 & 0.284639 & 0.7765 \\
$R O A$ & -0.053059 & -0.864747 & 0.3892 \\
SIZE & 0.104218 & 5.931966 & 0.0000 \\
LEVERAGE & -0.124889 & -3.058636 & 0.0028 \\
AGE & -0.083779 & -1.406553 & 0.1626 \\
$R 2$ & 0.320456 & & \\
Adj $R 2$ & 0.280087 & & \\
$F$-value & 7.938185 & & \\
Sig. & 0.000001 & & \\
$N$ & 108 & & \\
\hline \hline
\end{tabular}

Data processing results.

\section{Moderated Regression Analysis (MRA) Test}

The purpose of this interaction test was to see if the EY variable could moderate the independent variable with the dependent variable. Table IV summarizes the results of the MRA analysis.

TABLE IV: MODERATING TEST

\begin{tabular}{cccc}
\hline \hline Variabel & Coeff. & t-statistic & p-value \\
\hline$C$ & 0.061308 & 0.821995 & 0.4130 \\
$P C \_C O M$ & -0.038515 & -0.987007 & 0.3260 \\
$E Y$ & -0.005675 & -0.311319 & 0.7562 \\
ROA & -0.066925 & -1.071313 & 0.2866 \\
SIZE & 0.105469 & 6.000115 & 0.0000 \\
LEVERAGE & -0.128011 & -3.132560 & 0.0023 \\
AGE & -0.078671 & -1.318969 & 0.1902 \\
MODERATING & 0.090107 & 1.137351 & 0.2581 \\
R2 & 0.329134 & & \\
Adj $R 2$ & 0.282174 & & \\
F-value & 7.008731 & & \\
Sig. & 0.000001 & & \\
$N$ & 108 & & \\
\hline \hline
\end{tabular}

Data processing results.
The MRA test results show that the leverage and SIZE variables have a significant effect on ABTD with values of 0.0023 and 0.0000 . The PC_COM, EY, ROA, and AGE variables have no significant effect. In this test, moderation is a variable used to test the ability of the EY variable to moderate between PC_COM and ABTD. The moderating value in the test is 0.2581 , indicating that the $\mathrm{EY}$ variable does not have the ability to moderate PC COM and ABTD. The second hypothesis, that the electoral year exacerbates the negative effect of political connections on tax avoidance, is rejected. In terms of tax avoidance, the electoral year, which becomes the political year for the implementation of general elections in Indonesia, has no significant effect.

\section{Additional Analysis}

There are two variables that have a significant effect, namely the leverage variable, which has a significance value of 0.0028 , and the size variable, which has a significance value of 0.0000 . With this reference, the researchers conducted an in-depth study that included group regression with a focus on three variables.

TABLE V: ANALYSIS OF VARIABLE EY

\begin{tabular}{ccccccc}
\hline \hline \multirow{2}{*}{ Variabel } & \multicolumn{3}{c}{ Dummy 0 } & \multicolumn{3}{c}{ Dummy 1 } \\
\cline { 2 - 7 } & Coeff. & t-statistic & p-value & Coeff. & t-statistic & p-value \\
\hline C & 0.0790 & 0.9233 & 0.3589 & -0.0689 & 0.4066 & 0.6879 \\
PC_COM & -0.0404 & -1.0186 & 0.3118 & 0.0850 & 1.0671 & 0.2965 \\
ROA & -0.0325 & -0.4226 & 0.6738 & -0.1544 & 1.2860 & 0.2107 \\
SIZE & 0.1164 & 5.7295 & 0.0000 & 0.0780 & 2.1437 & 0.0424 \\
LEV & -0.1360 & -2.7130 & 0.0083 & -0.0910 & 1.2268 & 0.2318 \\
AGE & -0.0966 & -1.4183 & 0.1604 & 0.0287 & 0.2131 & 0.8330 \\
$R 2$ & 0.3800 & & & 0.2351 & & \\
Adj $R 2$ & 0.3370 & & & 0.0757 & & \\
F-value & 8.8290 & & & 1.4756 & & \\
Sig. & 0.0001 & & & 0.2345 & & \\
$N$ & 78 & & & 30 & & \\
\hline \hline
\end{tabular}

Data processing results. 
Table $\mathrm{V}$ is a data collection that includes dummy 0 for data collected prior to the electoral year, and dummy 1 for data collected during the electoral year. It is known that the size and leverage variables have a significant influence on the dummy 0 (zero) group, with values of 0.0000 and 0.0083 , respectively. When the general election is not held, companies with high total assets and leverage encourage tax avoidance practices due to the high volume of business, resulting in lower savings and tax costs. Dummy group 1 (one) contains variable size, which has a significant value of 0.0424 , while leverage has no effect. Debt is a legal obligation that is considered a company's financial burden with a fixed mechanism that is bound by an agreement and has severe legal ramifications. During an electoral year, things are different. Because of the high exposure of political figures affiliated with the company, companies with high and low debt tend to be tax compliant and obedient.

TABLE VI: ANALYSIS OF VARIABLE LEVERAGE

\begin{tabular}{|c|c|c|c|c|c|c|}
\hline \multirow{2}{*}{ Variabel } & \multicolumn{3}{|c|}{$<0.5367$} & \multicolumn{3}{|c|}{$>0.5367$} \\
\hline & Coeff. & t-statistic & p-value & Coeff. & t-statistic & p-value \\
\hline$C$ & 0.1946 & 1.7310 & 0.0899 & -0.1016 & -1.1340 & 0.2624 \\
\hline PC_COM & 0.0200 & 0.4699 & 0.6405 & -0.1576 & -1.9000 & 0.0634 \\
\hline$R O A$ & 0.1291 & 1.2438 & 0.2196 & -0.0896 & -1.2906 & 0.2030 \\
\hline SIZE & 0.1144 & 4.0146 & 0.0002 & 0.1211 & 5.1929 & 0.0000 \\
\hline$E Y$ & $\begin{array}{c}- \\
0.0042\end{array}$ & -0.1711 & 0.8648 & 0.0048 & 0.2437 & 0.8085 \\
\hline$A G E$ & $\begin{array}{c}- \\
0.2560\end{array}$ & -2.6497 & 0.0109 & -0.0109 & -0.1376 & 0.8911 \\
\hline$R 2$ & 0.3215 & & & 0.3833 & & \\
\hline$A d j R 2$ & 0.2508 & & & 0.3191 & & \\
\hline$F$-value & 4.5490 & & & 5.9686 & & \\
\hline Sig. & 0.0017 & & & 0.0002 & & \\
\hline$N$ & 54 & & & 54 & & \\
\hline
\end{tabular}

Data processing results.

Table VI has a median value of 0.5367 , which separates company data. It is known that the size and age variables have a significant effect in the group of companies with leverage below the median, with values of 0.0002 and 0.0109 , respectively. Size is similar to the previous regression, which produced significant results, so it can be concluded that leverage below the middle value has a significant effect on tax avoidance. Low debt but high total assets encourage companies to avoid taxes because of the tendency of less productive assets so that company efficiency by reducing tax costs is an option. Age has a significant effect on tax avoidance because when a company's debt is low but its total assets are high, and the company's age is long enough, it encourages company management to do more mature tax planning.

In the group above the median value, the size variable has a significant effect on tax avoidance. This result is the same as the equation model based on the group below the median, so it can be concluded that the size of the company has a significant effect on tax avoidance regardless of the leverage value of the company. The higher the company's debt burden, the higher the costs incurred, so tax avoidance is one of the possible policies to pursue.

The score of the PC variable is almost close to the significant value of 0.0634 at the $10 \%$ level in the additional analysis of Table VI with the group regression model separating the leverage variable above the median value of 0.5367200 . According to the test results, when the data is divided into two, the PC_COM variable begins to show a significant value to tax avoidance when the company has a high leverage value. It can be explained that when the company has a high debt value, the company's assets will increase. High leverage indicates that creditors have a high level of trust in company executives. As one of the requirements for applying for debt, the board of commissioners is one of the parties who signs the financial statements. As a result of the board of commissioners' guarantee of security in access to government resources, creditors can distribute funds more easily

\begin{tabular}{ccccccc}
\multicolumn{7}{c}{ TABLE VII: ANALYSIS OF VARIABLE SIZE } \\
\hline \hline \multirow{2}{*}{ Variabel } & \multicolumn{5}{c}{$<$ Rp. 4,45 T } & \multicolumn{3}{c}{$>$ Rp. 4,45 T } \\
\cline { 2 - 7 }$C$ & Coeff. & t-statistic & p-value & Coeff. & t-statistic & p-value \\
\hline PC_CO & 0.2708 & 2.5012 & 0.0158 & -0.0072 & -0.0674 & 0.9465 \\
$M$ & -0.0294 & -0.6362 & 0.5277 & -0.0644 & -1.1652 & 0.2497 \\
$R O A$ & -0.3461 & -4.0162 & 0.0002 & 0.1425 & 1.6803 & 0.0994 \\
$L E V$ & -0.1748 & -2.9359 & 0.0051 & -0.0902 & -1.5378 & 0.1307 \\
$E Y$ & 0.0145 & 0.7968 & 0.4295 & -0.0091 & -0.3652 & 0.7165 \\
AGE & -0.2188 & -2.6354 & 0.0113 & 0.0562 & 0.6502 & 0.5187 \\
$R 2$ & 0.4385 & & & 0.1968 & & \\
Adj $R 2$ & 0.3800 & & & 0.1131 & & \\
$F$-value & 7.4971 & & & 2.3524 & & \\
Sig. & 0.0029 & & & 0.0546 & & \\
$N$ & 54 & & 54 & & \\
\hline \hline
\end{tabular}

Data processing results.

Table VII shows a regression equation model based on dividing the size variable into two with a median value of IDR 4.45 trillion or 0.6492882 if converted to a logarithmic model. There are three variables that have a significant effect in the group whose sample is below the median, namely ROA, leverage, and age. A high ROA demonstrates the ability of a company's productive assets to generate profits. High profits with few assets are more likely to encourage companies to avoid paying taxes because the tax costs that arise cause company management to consider shifting to sectors that are more profitable for the company. Leverage and age have a significant effects on tax avoidance because companies with low total assets are not yet productive enough to save costs, including taxes. High leverage combined with low assets will have a significant effect on the company's finances, particularly liquidity to meet obligations. The maturity of management in managing tax policy is related to the age of the company. The mature age of the company will make tax accounting policies more precise because it is assumed that the size of the tax paid does not have a direct impact on the company.

There is no significant variable in the group with total assets exceeding Rp 4.45 trillion. These findings can be interpreted as indicating that companies with large total assets are more likely to be tax compliant because companies with large assets have a greater chance of being exposed to the public. Large assets allow investors to enter the political arena and position themselves as role models for the community. This is consistent with the number of investors who choose to be philanthropists, so it would be unfortunate if they encountered legal or tax issues. 


\section{CONCLUSION}

This study aims to determine the influence of political connections on tax avoidance, with the electoral year variable serving as a moderating variable. According to the findings, the political connection of the board of commissioners has an insignificant negatively affects on tax avoidance. This study also shows that the electoral year has no effect on the effect of the board of commissioners' political connections on tax avoidance.

This study's additional analysis reveals that variable size and leverage have a significant affects on tax avoidance. When a company's leverage value is high, the value of political connections rises to near-significant levels. When faced with high debt, companies have a tendency to use political connections because it ensures that politically affiliated companies are more likely to be bailed out during times of economic hardship [6] and [17].

\section{LIMITATION AND SUGGESTION}

There are several limitations in this research, as well as suggestions for future research. First, because the samples came from a variety of companies, the data obtained varied in terms of asset composition as well as accounting policies used in preparing financial statements. As a result, future research is expected to focus more on companies with similar characteristics in order to obtain similar data, resulting in more precise information.

Second, this research only searches the mass media and the internet for political connections by certain parties that are thought to have a basis and affiliation to political power in terms of parties, power holders, and legislators. As a result, future research will likely include other media in order to obtain more extensive and detailed information on political connections, such as the KPU (General Elections Commission) database, Bawaslu (General Election Supervisory Agency), legislative institutions, or political parties.

Third, electoral year data focusing on the general election of the President, DPR, MPR, and DPD are less than nonelectoral year data. It is preferable to extend the research period or to concentrate on the data during the electoral year.

\section{REFERENCES}

[1] Indonesian Ministry of Finance. Target dan Realisasi Penerimaan Pajak Tahun 2010-2020. From www.kemenkeu.go.id.

[2] S. Rego, R. Wilson, "Equity Risk Incentives and Corporate Tax Aggressiveness,"Journal of Accounting Research, vol. 50, no. 3, 2012. https://doi.org/10.1111/j.1475-679X.2012.00438.x.

[3] M. Hutchens, S. Rego, "Tax Risk and Cost of Equity Capital,"Indiana University Working Paper, 2013.

[4] C. Kim, Liandong, L. Zhang, "Corporate Political Connections and Tax Aggressiveness," Contemporary Accounting Research, vol. 33, no. 1, 2016. https://doi.org/10.1111/1911-3846.12150.

[5] N. Boubakri, S. A. Mansi, W. Saffar, "Political Institutions, Connectedness, and Corporate Risk Taking," Journal of International Business Studies, vol. 44, no. 3, 2013 https://doi.org/10.1057/jibs.2013.2.

[6] R. Duchin, D. Sosyura, "The Politics of Government Investment," Journal of Financial Economics, Vol. 106, No. 1. 2012. https://doi.org/10.1016/j.jfineco.2012.04.009.

[7] Masripah, V. Diyanty, D. Fitriasari, "Controlling Shareholder and Tax Avoidance: Family Ownership and Corporate Governance,"

International Research Journal of Business Studies, vol. 8, No. 3, 2015. https://doi.org/10.21632/irjbs.8.3.167-180.

[8] C. Kim, L. Zhang, "Corporate Political Connections and Tax Aggressiveness," Contemporary Accounting Research, vol. 33, no. 1, 2016. https://doi.org/10.1111/1911-3846.12150.

[9] B. A. Pranoto, A. K. Widagdo, "Pengaruh Koneksi Politik dan Corporate Governance Terhadap Tax Agressiveness," Syariah Paper Accounting FEB UMS, vol. 1, no. 3, 2015.

[10] CNN Indonesia. Panama Papers dan Praktik Penghindaran Pajak. From www.cnnindonesia.com. 2016.

[11] Suara. Fitra: Setiap Tahun Penghindaran Pajak Capai Rp 110 Triliun. From www.suara.com.2017.

[12] C. Leuz, F. O. Gee, "Political Relationships, Global Financing, and Corporate Transparency: Evidence from Indonesia," Journal of Financial Economics. vol. 81, no. 2, 2006. https://doi.org/10.1016/j.jfineco.2005.06.006.

[13] B. B. Francis, I. Hasan, X. Sun, Q. Wu, "CEO Political Preference and Corporate Tax Sheltering," Journal of Corporate Finance, vol, 38. p, 37-53. 2016. https://doi.org/10.1016/j.jcorpfin.2016.03.003.

[14] Y. A. Sudibyo, S. Jianfu, "Political Connections, State Owned Enterprises and Tax Avoidance: An Evidence from Indonesia," Corporate Ownership and Control, Vol. 13, No. 3, p. 279-183. 2016.

[15] W. A. Purnomo. Pengusaha Kuasai Parlemen. From www.tempo.co.id. 2019.

[16] T. Y. H. Tang, M. Firth, "Earnings Persistence and Stock Market Reactions to the Different Information in Book Tax Differences: Evidence from China," International Journal of Accounting, Vol. 47, No. 3, p. 369-397. 2012. https://doi.org/10.1016/j.intacc.2012.07.004.

[17] M. Faccio, "Politically Connected Firms," American Economic Review, vol. 96, no. 1, p. 369-386. 2006. https://doi: $10.1257 / 000282806776157704$.

[18] E. Sefiana, "Pengaruh Penerapan Corporate Governance terhadap Manajemen Laba pada Perusahaan Perbankan yang telah go Public di BEI," Jurnal Ekonomi Bisnis dan Akuntansi Ventura, Vol. 12, No. 3 , p. 211-222. 2009.

[19] T. Arifin, I. Hasan, R. Kabir, "Transactional and Relational Approaches to Political Connections and the Cost of Debt," Journal of

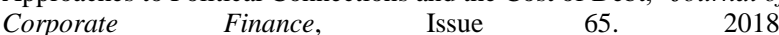
https://doi.org/10.1016/j.jcorpfin.2020.101768.

[20] K. A. Getz, "Public Affairs and Political Strategy: Theoretical Foundations," Journal of Public Affairs: An International Journal, Vol 1, No. 4, p. 305-329. 2001. https://doi.org/10.1002/pa.77.

[21] T. Arifin, I. Hasan, R. Kabir, "Does It Cost to Be Politically Connected? An Examination of the Grabbing Hand Hypothesis Using Corporate Taxes," SSRN Electronic Journal. 2019. http://dx.doi.org/10.2139/ssrn.3389381.

[22] J. P. Kotter, "Managing External Dependence," The Academy of Management Review, Vol. 4, No. 1, p. 87-92. 1979. https://doi.org/10.5465/amr.1979.4289188.

[23] S. D. Dyreng, J. L. Hoopes, J. H Wilde, "Public Pressure and Corporate Tax Behavior," Journal of Accounting Research, Vol. 54, No. 1, p. 147 186. 2016. https://doi.org/10.1111/1475-679X.12101.

[24] P. Iswari, E. A. Sudaryono, W. Widarjo, "Political Connection and Tax Aggressiveness: A Study on the State Owned Enterprises Registered in Indonesia Stock Exchange," Journal of International Studies. Vol. 12, No. 1, p. 79-92. 2019.

[25] Zulfitra, M. Tumanggor, "Pemilu Serentak 2019 di Indonesia Memberikan Pengaruh terhadap Likuiditas Saham Return Saham dan Harga Saham LQ 45 di Bursa Efek Indonesia," Jurnal Ekonomi Efektif, Vol. 2, No.1. 2019. http://dx.doi.org/10.32493/JEE.v2i1.3516.

[26] E. A. Sudaryono, Rahmawati, Djuminah, Wartono, W. Widarjo, "Relationship of Political Connection and Tax Aggressiveness: Empirical Evidence from Indonesia," International Journal of Economic Policy in Emerging Economies, 12(5), 453-465. 2019.

[27] R. E. Prasetyo, S. Raharja, "Analisis Pengaruh Kualitas Auditor dan Komite Audit terhadap Cost of Debt dengan Usia Perusahaan sebagai Variabel Pemoderasi (Studi pada Perusahaan yang Melakukan IPO di BEI Tahun 2008-2012)," Doktoral disertasi Fakultas Ekonomika dan Bisnis. Universitas Diponegoro. 2013.

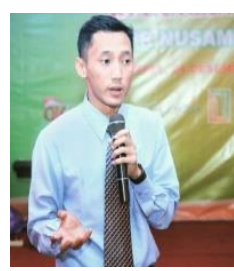

Boyolali.
Bambang Ahmad Indarto Born in Pati Central Java. $\mathrm{He}$ received him Bachelor degree from Semarang State University, majoring in accounting. He currently pursuing him Master degree at Sebelas Maret University majoring in Master of Accounting study program. He has worked as a Juior Auditor at The Public Accounting Firm Drs Suprihadi \& Rekan, Malang and Head of Operations at BPR Nusamba, 
Wahyu Widarjo is a Lecturer in Financial Accounting and Taxation at the Faculty of Economics and Business, Universitas Sebelas Maret, Indonesia. He holds a Doctoral degree from the Universitas Sebelas Maret, Indonesia. He has published a number of papers in reputed journals. 